\title{
Progressivism in British Politics: Some Revisionist Themes
}

\section{Ben Jackson}

\section{Faculty of History \& University College, Oxford University \\ benjamin.jackson@univ.ox.ac.uk}

It is a well-worn - although undeniable - historiographical cliché that all works of history reflect the concerns of the time in which they are written. In retrospect, a striking illustration of this phenomenon was the explosion in the late twentieth century of historical scholarship and political commentary on the so-called 'progressive alliance' between the Liberal Party and the infant Labour Party in the early twentieth century. In the late 1970s and 1980s, as the ideology of socialism began to crumble, and the revival of third party politics gathered momentum, historians and commentators became fascinated by the character of Liberal and Labour politics in the Edwardian period (c. 1901-14), when the two parties formed a powerful electoral force that vanquished the Conservatives in a landslide general election victory in 1906 and then in two close general elections in quick succession in 1910. A fundamental part of this successful alliance, it was argued, was a shared 'progressive' ideology that bound together moderate socialists with an emergent 'new liberalism' that sought to modernise liberal political ideas by addressing the pressing issues of unemployment, poverty, and economic inequality seemingly neglected by earlier classical liberal thinkers. ${ }^{1}$ The political implications of this historical scholarship were often left implicit, but other authors writing more directly at the interface between academic enquiry and public debate, perhaps most importantly David Marquand, drew on this research to make important interventions into the arguments over Labour's current political direction, and its relationship with other parties, particularly the SDP/Liberal Alliance and in due course the 
Liberal Democrats. Marquand's case was that Labour's political culture and ideology had, when pursued in isolation from the more pluralist Liberal tradition, proven to be politically brittle because it was often unattractive to middle opinion; too wedded sociologically to a defensive working class trade unionism; and even somewhat normatively unattractive in its uncritical acceptance of the existing constitutional structures of the British state. ${ }^{2}$ In essence, Marquand's case, which was echoed by many left-leaning commentators in the 1990s and then during the early years of the New Labour government, was that a renewed progressive alliance was desirable not just to remove the Conservatives from government, but also to develop a radical and attractive agenda for reform of the British economy and state.

In some respects these arguments of the 1990s seem rather distant from us, but it is clear that the core issue identified in this debate has, after Labour's exit from office in 2010, become highly salient once again. Can a strong non-Conservative political formation in Britain be forged out of the diverse strands of non-Conservative political ideas and identities that uneasily co-exist with each other in both the electoral and ideological arenas? The financial crisis of 2008-9; the general election of 2015; and the 2014 Scottish independence and 2016 Europe referendums have cumulatively created a genuine crisis for the future of progressive politics in Britain. The prospects for a new progressive alignment seem at present rather dim, but in the rest of this article I want to argue that a return to the history of progressive political thought can nonetheless help us to think afresh about what such a renewed centre-left politics might look like today. There are, I will suggest, some significant aspects of this history that attracted little attention in the 1980s and 1990s, but which seem much more important today. This revisionist mini-history of British progressivism inevitably inflected by its composition after the financial crisis and the consequent rise of populist nationalisms and anti-capitalisms of various hues - points the way towards some 
common ideological ground that could provide a starting point for further dialogue between different 'progressive' political parties and interests.

\section{Socialism}

One attraction of the Lib-Lab progressivism of the early twentieth century to commentators and political actors in the 1980s and 1990s was that it conjured up a leftist discourse that was apparently untainted by the perceived shortcomings of post-1945 Labour socialism. Instead, a return to the insights of an earlier new liberalism, and in turn its influence on Labour's political thought, was said to furnish the left with a progressive ideology that prescribed an active state working with a broadly market economy rather than the more systematic aspirations to abolish the market altogether believed to be associated with full-blooded democratic socialism. The version of the new liberalism that was most widely discussed was one that sought to ameliorate the inequalities and inefficiencies of the market through progressive taxation, building the welfare state, regulating the labour market, and undertaking counter-cyclical public spending. Yet, as I have argued elsewhere, there was something significant missing from this account of the new liberalism, namely the extent to which leading new liberal thinkers were themselves deeply influenced by British socialism, to the extent that, in addition to the familiar tools of fiscal policy and state regulation, they also supported a strategic role for social ownership in the economy. ${ }^{3}$

Both Leonard Hobhouse and J. A. Hobson, the most celebrated theorists of the new liberalism in the early twentieth century, argued that it would be necessary to expand social ownership to achieve the economic and social freedoms that they prioritised. This could take the form of an expansion of municipal, co-operative, and national social ownership, with some flexibility as to which was the most appropriate model to pursue from case to case. 
Many of their most significant works contained Labour manifesto-style 'shopping lists' of industries that should be taken into public ownership. For Hobhouse, these typically included gas, water, transport, and the mines; for Hobson, it included the public ownership of banks; insurance; utilities such as water, electricity and gas; railways; oil; the mines; iron works; engineering shops; cotton; corn; sugar; and possibly agricultural land. ${ }^{4}$ Why did they favour this degree of social ownership? They invoked a number of reasons, but they (and their socialist contemporaries) were particularly concerned by the lack of accountability enjoyed by large industrial monopolies. New liberals and socialists in the first half of the twentieth century regarded the evolution of large corporations as an inevitable economic trend, with private monopolies or cartels ultimately emerging in many areas of industry. This view was coupled with scepticism about whether it would be possible to break-up such monopolies or render them more competitive while still retaining the efficiency advantages of large-scale production. As a result, Hobhouse and Hobson argued, the choice would in practice often be between a private monopoly - and all that implied in terms of unaccountable power - and a public monopoly - where it was assumed that a measure of democratic control could be exercised over the industry in question.

The extent of that democratic control - and whether it was exercised chiefly through local or national elected representatives appointing the management of an industry or more radical forms of worker participation - was a live issue in debates over social ownership in the early twentieth century. Hobhouse, Hobson and other left liberals were influenced by the international upsurge in labour protest in the years before and after the First World War and the resulting prominence of forms of socialism that foregrounded industrial democracy, such as syndicalism and guild socialism. As a result they ultimately favoured models of social ownership that incorporated worker participation. Hobhouse and Hobson envisaged a gradual evolution towards a mixed economy that would include nationalised industries, co-operatives, 
municipal enterprises, and private firms - the extent of each economic model being an empirical matter, dependent on the results each yielded in practice. They proposed nationalised industries managed by joint boards split into three equal sections, representing the interests of consumers, managers, and workers respectively. Co-operatives would be full worker-managed enterprises, while private firms would include formal mechanisms for worker consultation and profit-sharing schemes. As Hobson put it, the growth of social ownership would therefore signal 'the substitution of representative government for employers' autocracy.' 5

In one sense, then, the prevalence of socialism as an important influence on the new liberalism weakens the claim of exponents of 'progressivism' to have identified a novel pathway for a left-wing politics that remained neglected during the rest of the twentieth century. As we have seen, the new liberal and socialist agendas in fact converged with respect to public ownership as well as on the more familiar grounds of fiscal and social policy. Invocations of new liberal thought as a safely non-socialist progressive political ideology are therefore misplaced. On the other hand, the very fact that early twentieth century new liberals and socialists agreed on the strategic importance of social ownership - and on the wisdom of experimenting with diverse forms of it - does nonetheless have an intriguing contemporary political resonance. The systematic influence of large corporate interests over the British economy and polity has, in the wake of the financial crisis, rightly become the subject of renewed debate. Among the possible innovations canvassed to ameliorate the lack of accountability enjoyed by these interests, the establishment of new models of social ownership - whether co-operatives or outright nationalisation - has made a tentative return to British public debate. But - and here there is a difference with the nationalisations undertaken after 1945 - this new wave of arguments for socialism emphasises the importance of expanding worker participation in economic decision-making as a critical element of any new 
social ownership programme. ${ }^{6}$ In this sense, a return to the debates over ownership in the early twentieth century can indeed be seen as providing a distinctive, and perhaps even more radical, agenda for the left than the classic Labour socialism of 1945 and after.

\section{Nationalism}

In retrospect it is remarkable that one of the most fundamental features of the Edwardian political landscape - and the critical factor in the electoral survival of the new liberalism as a governmental project - was passed over with little comment by later enthusiasts for Lib-Lab progressivism when they explored the historical roots of their politics. Irish nationalism, and the Irish electoral dominance of the Irish Parliamentary Party after 1885, was apparently a subject of only tangential interest to the exponents of a revived liberal social democracy in the late twentieth century. Why that should have been the case is not entirely clear, since the putative liberal social democracy envisaged at that time was one that enthusiastically embraced devolution for Scotland and Wales, commitments in part driven by the electoral threat posed by the SNP and Plaid Cymru. Perhaps this latter concern helps to explain the lack of interest in Ireland, since progressivists of the 1980s and 1990s assumed that their electoral strategies were geared towards bringing together Labour and the SDP/Liberal Alliance or the Liberal Democrats, with nationalist parties, like the Conservatives, regarded as opponents to be defeated. It was therefore hard to see any contemporary use for the notion that there could be a progressive alliance not only between Liberals and Labour but also with Celtic nationalists. Yet it was in fact an alliance with Irish nationalists that sustained the Liberal Party in government after the two general elections of 1910, enabling the new liberalism to develop further in government and the long-awaited goal of Irish home rule to at last make some legislative progress. Of course, this history now appears much more relevant 
to the dilemmas faced by progressives today. A common argument - espoused for example by Neal Lawson, chair of the left-wing pressure group Compass - is that a renewed progressive alliance could bring together Labour in a grand anti-Conservative pact not only with the Greens and the Liberal Democrats but also with Plaid Cymru and the SNP. ${ }^{7}$ How might we evaluate this argument and its historical resonance?

To stick for the moment with the strictly historical point about the Edwardian progressive alliance, one response might be to caution that the links between Irish nationalism and British liberalism and socialism were in fact much more transactional and problematic than my initial gloss of them suggested. It was Gladstone’s support for home rule in Ireland that famously split the Liberal Party in 1886, after all, calling forth the Liberal Unionist Party that governed in coalition with the Conservatives from 1895 to 1905 and ultimately merged with the Conservatives in 1912. One important line of interpretation has therefore seen Gladstone’s decision to back home rule as ultimately destructive of the Liberals' electoral appeal as a 'national' party capable of commanding wide popular support. Instead, this argument continues, Liberal support for Irish home rule enabled the Conservatives to portray the Liberals as in hock to sectional interests that threatened the Union. ${ }^{8}$ Likewise, although the Liberals were forced to make progress on Irish home rule by dint of parliamentary arithmetic after 1910, it could be maintained that it was electoral bargaining or high political manoeuvring rather than a shared ideological commitment that drove the Edwardian progressive alliance with Irish nationalism. However, as Eugenio Biagini has recently argued, such arguments understate the extent to which in late nineteenth and early twentieth century Britain popular radicalism, liberalism and socialism all shared with Irish nationalism a language of liberty, citizenship and democracy that regarded the suppression of Irish freedom as an injustice in urgent need of redress and as emblematic of a wider humanitarian politics based on the moral priority of individual rights. This 
‘progressive’ politics was animated by a republican understanding of liberty as selfgovernment and a pluralistic vision of how the British union-state might accommodate the self-government of its constituent nations. It was also a progressive politics that was able to mobilise popular support in the Edwardian period. ${ }^{9}$

But while from a historical perspective there is certainly a case to be made for a genuine progressive alliance between nationalism, liberalism and socialism, the historical analogy between contemporary politics and this earlier period is an imperfect one, in the sense that the alliance with Irish nationalists was constructed over securing 'home rule' for Ireland and not Irish independence. 'Home rule' was of course a deliberately ambiguous term, which was intended to yoke together a wide coalition of support behind greater political autonomy for Ireland without necessarily specifying the precise extent of the powers that would be granted to a new Irish parliament. But however vague as a guide to any reformed constitutional settlement, 'home rule' for Ireland was generally understood to entail that Ireland would remain part of a political union with the rest of the United Kingdom. ${ }^{10}$ It was only later, following the radicalisation of Irish politics after 1916, that a more separatist form of Irish nationalism came to the fore. The disanalogy with today is therefore that 'home rule' has already been granted to Scotland - though no doubt further discussion can and will be had over the precise powers that should be exercised by the Scottish Parliament. The debate sparked by the SNP is over whether there should be a separate Scottish state that no longer remains part of a political union with the rest of the United Kingdom. It is therefore harder to see room for negotiation or compromise given the specificity of this demand compared to the vagueness of the goal of Irish home rule.

What could therefore be the basis of a progressive alliance that incorporated the SNP? There is some wishful thinking about this on the English left, in the sense that it is often argued that a shared anti-austerity economic policy could bind together Labour, the Greens, 
the SNP, Plaid Cymru and perhaps now the Liberal Democrats. This may ultimately prove to be a tactical gambit worth trying to remove the Conservatives from power, but we should acknowledge that it is not in fact in the interests of the SNP to have a successful left-wing anti-austerity government run from Westminster. If such a government did emerge, then the fundamental rationale for Scottish independence articulated by SNP strategists for the last three decades would be seriously undermined. The core SNP argument for Scottish independence is that right-wing government is now an endemic feature of English politics and that Scotland can only pursue a more left-wing course once independent of Westminster rule. ${ }^{11}$ A left-wing government in London, supported by the SNP, would present a severe problem for this narrative. For such an alliance to work as effectively as it did in the Edwardian period, it would be necessary for the SNP to undertake a fundamental reappraisal of (or simply to deprioritise) its stance towards political union with the rest of the United Kingdom. Although unlikely at present, such a change is ultimately not inconceivable were the SNP to lose another referendum on Scottish independence. It is also possible that a government committed to a fundamental reappraisal of the British constitution, perhaps through a formal constitutional convention, might be able to draw the SNP into a stable political alliance, were the terms of reference of such a convention to be wide-ranging enough to enable the SNP leadership to sell participation in it to their supporters.

\section{Distributism}

After 2010 the exponents of Blue Labour formulated a powerful criticism of the historical retrieval of a shared 'progressivism' binding together the British liberal and Labour traditions. No doubt influenced at some level by the changed dynamics of the relationship between Labour and the Liberal Democrats after the formation of the Coalition government 
in 2010, Blue Labour thinkers such as Maurice Glasman, Jonathan Rutherford, Jon Cruddas and Marc Stears sought to characterise the authentic Labour tradition as one that grew from mutualist initiatives in working class collective action and that was therefore largely opposed to the individualism, modernism and technocracy that in their view shaped the outlook of liberals. ${ }^{12}$ While this is a bold and rather sweeping claim, which is vulnerable to a number of persuasive counter-arguments, ${ }^{13}$ it does highlight the extent to which the version of the British liberal tradition that has influenced recent British policy debates is heavily weighted towards the new liberalism. The great names of British liberalism that are customarily invoked with respect to progressivism tend to be intellectuals such as Hobson, Hobhouse, William Beveridge and John Maynard Keynes, with politicians such as David Lloyd George also called in aid. The liberalism that emerges is thus primarily focused on the expansion of state capacity and active government in order to reduce inequality and poverty through the welfare state and full employment. Such policies, which reached their zenith in British politics after the Second World War, do indeed tend to be focused on increasing the power of the central state and require high levels of technocratic expertise in their construction and implementation.

However, some important recent research has provided a valuable correction to this dominant perception of twentieth-century British liberalism. Stuart White and Peter Sloman have shown that, alongside the broadly new liberal currents discussed above, there has also been a mutualist and dispersive strand of liberalism that focused on civil society activism, greater democracy in industry and the state, and breaking up concentrations of economic and political power. ${ }^{14}$ This latter commitment prompted mid-century British liberals to revitalise older radical visions of an economy characterised by a more dispersed and ultimately egalitarian distribution of private property. The prominence of this strand of liberalism owed much to the Liberal activist and publicist Elliott Dodds, who from the 1930s onwards was an 
unflagging exponent within the Liberal Party of a distinctive, republican social vision based on creating a society of free, independent citizens, each possessing sufficient property to liberate themselves from dependence on employers or the state and thus autonomously pursue their own path in life. On this account, liberalism differed from conservatism in that it set out to diffuse economic ownership and power throughout society rather than leaving it in the hands of a minority class of owners, but it also - or so Dodds argued - differed from socialism in that it did not aim simply to replace this class system with a monopolistic form of state ownership. This led Dodds and other leading Liberals who were influenced by his analysis, such as Jo Grimond, the Party’s leader between 1956 and 1967, to advocate policies designed to widen private property-ownership and democratise industry, including more stringent inheritance and capital taxation; tougher anti-trust legislation; measures to advance greater equality of educational opportunity; and the promotion of profit-sharing and copartnership in industry. These policies were coupled with a more general organisational emphasis on local grass-roots politics and a rhetoric that focused on the unaccountable power wielded by both the centralised British state and large corporations.

There is therefore an intriguing affinity between this strand of the British liberal tradition and the ideas associated with Blue Labour. Although the most influential Blue Labour arguments were ostensibly anti-liberal, in fact Blue Labour thinkers share with liberals such as Dodds and Grimond an ideological commitment to decentralising political and economic power. This suggests that even with what seems like the hardest case for establishing a shared 'progressive' political project - Blue Labour - an agenda can be delineated that could in fact bind together Labour with the Liberal Democrats.

\section{Conclusion}


The chief aim of this article has been to establish that the history of progressivism still has political relevance for the British Left, even after the end of the Great Moderation that enabled debates around Lib-Lab relations in the 1980s and 1990s to coalesce around a tacit alliance over a modernising form of market-friendly social democracy. While those days of strong economic growth, bountiful tax revenues, and increased public spending are now in the past, the changed political situation after the financial crisis - with its anti-corporate populism, resurgent nationalisms, and state scepticism - could nonetheless still generate a progressive form of politics that seeks to combine certain strands of liberal, socialist and perhaps nationalist politics that were neglected in the earlier historiography and commentary on British progressive traditions.

However, this is of course a purely ideological point - it says nothing about the daunting practicalities involved in constructing such a progressive alliance. In particular, such a feat of coalition-building would require gifted political leadership, since the 2015 general election gave an intimation of how difficult it would be to construct a non-Conservative parliamentary bloc in the face of implacable Conservative and media opposition, tribal party alignments, and a popular distrust of backroom deals that would purportedly subvert the 'clarity' offered by the first past the post electoral system. The leaders of the progressive parties would therefore need to furnish the electorate, and their own supporters, with a clear and compelling story about how an anti-Conservative alignment would serve the national interest. There is therefore little prospect of such a renewed progressive alliance emerging in this parliament. Gifted political leadership is currently in short supply in all of the parties of the centre or left, with the exception of the SNP, and Nicola Sturgeon in any case has her own agenda to pursue for now. In all likelihood, we can expect a great deal of unfocused talk about the need for a new progressive alliance in the next few years but very little in terms of concrete efforts to map out the ideology, policy, and political strategy that might underpin it. 
Not for the first time in modern British political history, the Conservatives will continue to benefit from their opponents’ lack of seriousness about obtaining power.

\section{Notes}

${ }^{1}$ See for example P. Clarke, Liberals and Social Democrats (Cambridge, Cambridge University Press, 1978); M. Freeden, The New Liberalism (Oxford, Oxford University Press, 1978); M. Freeden, Liberalism Divided (Oxford, Oxford University Press, 1986); D. Tanner, Political Change and the Labour Party, 1900-18 (Cambridge, Cambridge University Press, 1990).

${ }^{2}$ D. Marquand, The Unprincipled Society (London, Fontana, 1988); D. Marquand, The Progressive Dilemma (London, Weidenfeld \& Nicolson, 1999); for Marquand’s own acknowledgement of the influence of the historiography of progressivism on his work, see his The New Reckoning (Cambridge, Polity, 1997), pp. 24-5.

${ }^{3}$ B. Jackson, 'Socialism and the New Liberalism', in B. Jackson and M. Stears (eds.), Liberalism as Ideology: Essays in Honour of Michael Freeden (Oxford, Oxford University Press, 2012), pp. 34-52. This section of this article draws on research previously published in this chapter.

${ }^{4}$ L. T. Hobhouse, Liberalism (Cambridge, Cambridge University Press, 1994 [1911]), pp. 467; L. T. Hobhouse, Elements of Social Justice (London, George Allen \& Unwin Ltd, 1922), pp. 177-82; J. A. Hobson, The Social Problem (London, J. Nisbet, 1902), pp. 176-7, 193; see also p. 179.

${ }^{5}$ J. A. Hobson, Incentives in the New Industrial Order (London, Leonard Parsons, 1922), pp. 35-6, 5, 100-12, 152-3, 156; Hobhouse, Elements, pp. 177-84. 
${ }^{6}$ J. Guinan, 'Social Democracy in the Age of Austerity and Resistance: The Radical Potential of Democratising Capital’, Renewal, 20 (2013), pp. 9-19; J. Guinan, ‘Who’s Afraid of Public Ownership?’, Renewal, 21 (2014), pp. 77-84.

${ }^{7}$ N. Lawson, 'Dear SNP’, OpenDemocracy, 31 May 2016, at https://www.opendemocracy.net/uk/neal-lawson/dear-snp (accessed 26 November 2016).

${ }^{8}$ See for example the influential J. Parry, The Rise and Fall of Liberal Government in Victorian Britain (New Haven, Yale University Press, 1993).

${ }^{9}$ E. Biagini, British Democracy and Irish Nationalism 1876-1906 (Cambridge, Cambridge University Press, 2007), especially pp. 1-5, 34-44, 372-3.

${ }^{10}$ A. Jackson, Home Rule: An Irish History 1800-2000 (London, Weidenfeld and Nicolson, 2003), pp. 28-234.

${ }^{11}$ B. Jackson, ‘The Political Thought of Scottish Nationalism', Political Quarterly, 85 (2014), pp. 50-6.

${ }^{12}$ M. Glasman, J. Rutherford, M. Stears and S. White (eds.), The Labour Tradition and the Politics of Paradox (London, the Oxford London Seminars/Soundings, 2011).

${ }^{13}$ B. Jackson, ‘Labour History and Glasman’s Labour Tradition’, in Glasman, Rutherford, Stears and White (eds.), Labour Tradition and the Politics of Paradox, pp. 38-41; J. Lawrence, 'Blue Labour, One Nation Labour, and the Lessons of History’, Renewal, 21 (2013), pp. 6-13.

${ }^{14}$ S. White, “"Revolutionary Liberalism?” The Philosophy and Politics of Ownership in the Post-War Liberal Party’, British Politics, 4 (2009), pp. 164-87; P. Sloman, The Liberal Party and the Economy, 1929-64 (Oxford, Oxford University Press, 2015), pp. 120-5, 190-5, 233-4. 